\title{
Cenzura przekładu Nowego Testamentu autorstwa Jakuba Wujka. Próba rekonstrukcji podziału prac między cenzorami ${ }^{1}$
}

\author{
Tadeusz Rubik \\ Uniwersytet Warszawski \\ t.rubik@uw.edu.pl (D) https://orcid.org/0000-0001-7647-2192
}

Decyzję o podjęciu inicjatywy nowego przekładu Biblii na język polski podjęła kongregacja prowincjonalna Towarzystwa Jezusowego w maju 1584 roku w Kaliszu² ${ }^{2}$ Być może już wówczas zadanie to powierzono Jakubowi Wujkowi, skoro to on został jesienią 1584 roku wysłany do Rzymu jako prokurator, czyli przedstawiciel prowincji, w celu przedstawienia jej postulatów Klaudiuszowi Aquavivie, generałowi zakonu. Podczas pobytu w Wiecznym Mieście Wujek uzyskał niezbędną zgodę na tłumaczenie i publikację wernakularnego Pisma Świętego udzieloną przez generała po konsultacji z papieżem Grzegorzem XIII. Warunkiem tego pozwolenia było uważne zweryfikowanie przekładu przed drukiem ${ }^{3}$, tj. poddanie go wewnątrzzakonnej cenzurze. Podlegały jej wszystkie dzieła opracowywane przez jezuitów ${ }^{4}$.

Ten warunek stał się jednak przyczyną konfliktu między Jakubem Wujkiem a częścią jezuitów, konfliktu, który wpłynął na ostateczny kształt przekładu. Dekret soboru trydenckiego stwierdzal, aby Wulgata, czyli „to stare i powszechnie uznane wydanie, które będąc w użyciu przez tyle stuleci zdobyło

1 Praca naukowa finansowana ze środków budżetowych na naukę w latach 2018-2022 jako projekt badawczy w ramach programu Diamentowy Grant.

2 Zob. K. Drzymała, Wpływ księdza Stanisława Grodzickiego T.J. na tłumaczenie Biblii ks. Jakuba Wujka T.J., „Polonia Sacra” 4 (1951) nr 1, s. 72; R. Pietkiewicz, Biblia Polonorum. Historia Biblii w języku polskim, t. 1: Od początku do 1638 r., Poznań 2016, s. 456; J. Poplatek, Obecny stan badań nad życiem Jakuba Wujka T.J. i program dalszej pracy, „Polonia Sacra” 3 (1950) nr 1-2, s. 53; W. Smereka, Wstęp, [w:] Nowy Testament, w przekł. J. Wujka z roku 1593, wstępem i uwagami poprzedził W. Smereka, Kraków 1966, s. XXVII-XXVIII.

3 Zob. K. Drzymała, Wpływ księdza Stanisława Grodzickiego T.J. na tłumaczenie Biblii ks. Jakuba Wujka T.J., dz. cyt., s. 72; R. Pietkiewicz, Biblia Polonorum..., dz. cyt., t. 1, s. 456; J. Poplatek, Obecny stan badań nad życiem Jakuba Wujka T.J. i program dalszej pracy, dz. cyt., s. 53, W. Smereka, Wstęp, dz. cyt., s. XXVIII.

4 Zob. np. J. Kochanowicz, Początki piśmiennictwa jezuickiego w Polsce. Studium z historii kultury, Wrocław 2012, s. 33. 
sobie uznanie w Kościele, było traktowane jako autentyczne w nauczaniu publicznym, w dysputach, kazaniach i wykładach”5. Jak przekonująco dowodzi David Frick, to właśnie interpretacja tego enigmatycznego sformułowania poróżniła polskich jezuitów ${ }^{6}$. Wujek uważał, że choć podstawą przekładu jest oczywiście zaaprobowany przez Kościół tekst Wulgaty, to jako tłumaczowi wolno mu w niektórych sytuacjach odwoływać się również do tekstu greckiego, a w wypadku Starego Testamentu - także hebrajskiego, na co wskazują rozbudowane nazwy wydań Nowego Testamentu z lat $1593^{7}$ i $1594^{8}$ oraz Psatterza Dawidów ${ }^{9}$.

Takie podejście wzbudziło jednak opór Stanisława Grodzickiego. Jeszcze przed ukazaniem się Nowego Testamentu z roku 1593 sformułował on ostrą krytykę i przedstawił postulat werbalistycznego tłumaczenia Wulgaty. Wiedzę o strategii translatorskiej Wujka zaczerpnął od cenzorów weryfikujących przekład, negatywny osąd utrwalił na podstawie oglądu fragmentów, które zdążyły ukazać się w innych dziełach tłumacza (przede wszystkim w Postylli katolicznej):

jak słyszę, ojciec Jakub Wujek bardziej zwraca uwagę nie tyle na słowa, ile na sens zaczerpnięty z tekstu greckiego. Uważam, że podążą za tym wszystkie największe trudności. [...] należy zalecić, aby od wydania Wulgaty, które aprobował święty sobór trydencki, jeśli to tylko będzie możliwe, nie oddalało się ani na grubość paznokcia [...] i tłumaczyło się jak najwłaściwiej słowo słowem, by [Wujek] nie rozważał, czy tłumaczenie jest eleganckie (do czego, jak się obawiam, dąży), lecz aby było prawdziwe - w taki sposób, żeby zachowany był sens gramatyczny. Jeśli tak się stanie,

5 Sesja czwarta, dekret II: Przyjęcie wydania Biblii zwanej Wulgata oraz o sposobie interpretacji Pisma Świętego, [w:] Dokumenty soborów powszechnych. Tekst łaciński i polski, t. 4.1, układ i oprac.

A. Baron, H. Pietras, Kraków 2007, s. 213-214.

6 D. Frick, Polska philologia sacra w czasach reformacji i kontrreformacji. Kilka kart z historii sporów wyznaniowych (1551-1632), przeł. K. Szymańska, Warszawa 2018, s. 186-187 (Studia o Literaturze Dawnej, 7).

7 Nowy Testament Pana naszego Jezusa Chrystusa, znowu z łacińskiego i z greckiego na polski wiernie a szczyrze przełożony i argumentami abo summariuszami każdych ksiag i rozdziałów, i annotacyjami po brzegach objaśniony [...], przeł. J. Wujek, w drukarni Andrzeja Piotrkowczyka, Kraków 1593.

8 Nowy Testament Pana naszego Jezusa Chrystusa, znowu z łacińskiego i greckiego na polskie wiernie a szczyrze przełożony, w drukarni Andrzeja Piotrkowczyka, przeł. J. Wujek, Kraków 1594.

9 Psałterz Dawidów. Teraz znowu z łacińskiego, z greckiego i z żydowskiego na polski język z pilnościa przełożony [...], przeł. J. Wujek, w drukarni Andrzeja Piotrkowczyka, Kraków 1594. 
łatwo będzie można je bronić przed heretykami: tłumacz postępował za Wulgatą, a na rzecz Wulgaty mamy liczne i dobre argumenty ${ }^{10}$.

Na tym etapie zastrzeżenia Grodzickiego nieco skomplikowały sytuację, lecz nie spowodowały daleko idących zmian w przekładzie. Wujkowi udało się doprowadzić do wydania Nowego Testamentu w 1593 roku, który został zweryfikowany przez cenzorów, wówczas jednak nie realizowano radykalnych postulatów Grodzickiego. Rok później (1594) ukazało się wydanie Nowego Testamentu, które dziś nazwalibyśmy popularnym: pozbawione obszernego naukowego paratekstu oraz not marginalnych i komentarzy o charakterze konfesyjnym (uzasadniających słuszność wiary katolickiej na podstawie poszczególnych miejsc Biblii), które znajdowały się w wydaniu z roku 1593, ponadto poprawione na podstawie tekstu Wulgaty syksto-klementyńskiej z 1592 roku, a także Psałterz Dawidów.

Przekład pozostałych ksiąg Starego Testamentu Wujek ukończył zimą 1596 roku, krótko przed śmiercią, która nastąpiła 27 kwietnia 1597 roku. Na zebranej w sierpniu kongregacji generalnej podjęto decyzję o ponownej weryfikacji całości tłumaczenia ${ }^{11}$. Można przypuszczać, że zadecydowano tak dlatego, iż Wujek nie mógł już samodzielnie obronić swojego tłumaczenia, być może również sytuacja religijna w Polsce zmieniła się na tyle, że daleko idące modyfikacje przekładu uznano za wskazane ${ }^{12}$. Zadanie powierzono grupie jezuitów, w tym Stanisławowi Grodzickiemu, którzy podjęli prace w Poznaniu i zaproponowali liczne zmiany - objęły one około 64 proc. wersetów w Psałterzu ${ }^{13}$ oraz około połowy w ewangeliach ${ }^{14}$. Kompletne, ocenzuro-

10 Cyt. za: J. Poplatek, Obecny stan badań nad życiem Jakuba Wujka T.J. i program dalszej pracy, dz. cyt., s. 59-60, przypis 122 (tłum. T. Rubik).

11 Por. K. Drzymała, Wpływ księdza Stanisława Grodzickiego T.J. na tłumaczenie Biblii ks. Jakuba Wujka T.J., dz. cyt., s. 78-79; R. Pietkiewicz, Biblia Polonorum..., dz. cyt., t. 1, s. 458-459; J. Poplatek, Obecny stan badań nad życiem Jakuba Wujka T.J. i program dalszej pracy, dz. cyt., s. 64-65.

12 Mogła się do tego przyczynić np. ostra krytyka obranej przez Wujka strategii translatorskiej przez Marcina Czechowica w dziele Plastr na wydanie Nowego Testamentu przez x. Jakuba Wujka [...]. [Aleksy Rodecki, Kraków 1594]. Brutalną, wydaną pod pseudonimem replikę na ten druk przypisuje się Marcinowi Łaszczowi, jednemu z cenzorów przekładu Biblii Wujka: [M. Łaszcz], Recepta na plastr Czechowica ministra nowokrzczeńskiego [...], w drukarni Łazarzowej, Kraków 1597.

13 K. Gąsiorowski, Dwa psałterze ks. Wujka, „Ruch Biblijny i Liturgiczny” 14 (1959) nr 3, s. 246-259, https://doi.org/10.21906/rbl.2719.

14 G. Borysławska, Różnice między kolejnymi wydaniami Nowego Testamentu $w$ przekładzie Jakuba Wujka, „Acta Universitatis Lodziensis. Folia linguistica” 1 (1981), s. 10, http://hdl.handle. 
wane wydanie Biblii ukazało się w roku $1599^{15}$. Motywację wprowadzonych zmian przedstawia fragment Apparatus sacer (przedmowy):

co się dotycze tekstu samego, ten przełożony jest z łacińskiego starego tekstu, który zowią Vulgatam editionem [...]. Tenże tekst tu masz wiernie przełożony i według tej ostatniej korekcyjej [Wulgaty syksto-klementyńskiej z roku 1593] poprawiony. I przetoż i Nowy Testament, i Psałterz, który już przedtym był po polsku wydany, teraz jeszcze znowu przejrzany jest z i [sic!] lacińskim zniesiony, aby się jako nawłaśniej z łacińską Wulgatą zgadzał, bo się w pierwszej edycyjej w niektórych rzeczach greckiego tekstu dla tych, którzy tego pragnęli, naśladowało, co teraz wszystko odrzuciwszy, masz tu szczerze tekst łaciński jako sam w sobie jest ${ }^{16}$.

Ustalenia badawcze potwierdzają, że zgodnie z tą deklaracją oraz postulatem Grodzickiego zawartym w omówionym wyżej liście, jak pisze Grażyna Borysławska, „wierne dostosowywanie przekładu do tekstu łacińskiego doprowadziło do zlatynizowania i do okaleczenia tekstu"17.

Kim byli jezuici zaangażowani w cenzurę przekładu Wujka? Trzy źródła podają niezupełnie ścisłe, choć komplementarne informacje. Kacper Wielewicki w Dzienniku spraw domu zakonnego napisał, że prace w ciągu sześciu miesięcy przeprowadzili Stanisław Grodzicki, Adrian Radzimiński, Justus Rabb, Jan Brant oraz Marcin Łaszcz, w innym miejscu jednak, w biogramie Justa Rabba, nie wymienia Łaszcza. Z kolei redaktor Annales Collegii Posnaniensis wspominał, że zadanie w ciągu roku wykonało trzech braci, nie wskazując jednak ich tożsamości ${ }^{18}$. Według badaczy oznacza to, że w części prac uczestniczyli tylko niektórzy cenzorzy, w pozostałych zaś wszyscy, tj. cała

net/11089/14568.

15 Biblia to jest księgi Starego i Nowego Testamentu według łacińskiego przekładu starego, $w$ kościele powszechnym przyjętego, na polski język znowu z pilnościa przełożone [...], przeł. J. Wujek, w drukarni Łazarzowej, Kraków 1599.

16 [M. Łaszcz], Apparatus sacer, [w:] Biblia..., Kraków 1599, k. ***iiii 1.

17 G. Borysławska, Różnice między kolejnymi wydaniami Nowego Testamentu w przekładzie Jakuba Wujka, dz. cyt., s. 17; por. K. Drzymała, Wpływ księdza Stanisława Grodzickiego T.J. na tłumaczenie Biblii ks. Jakuba Wujka T.J., dz. cyt.; K. Gąsiorowski, Dwa psatterze ks. Wujka, dz. cyt.; J. Frankowski, Psałterz Dawidów z 1594 roku w przekładzie ks. Jakuba Wujka i jego znaczenie, [w:] Psałterz Dawidów w przekładzie ks. Jakuba Wujka z 1594 roku, oprac. J. Frankowski, Warszawa 1993, s. 16-17.

18 Źródła omawia R. Pietkiewicz, Problematyka żydowska w Biblii księdza Jakuba Wujka z 1599 roku. Studium źródet, „The Biblical Annals” 10 (2020) nr 2, s. 282-283, przypisy 17-18, https://doi. org/10.31743/biban.4691. 
piątka ${ }^{19}$. Szczegółowy opis wydarzeń, tutaj tylko zarysowanych, można znaleźć w pracach Kazimierza Drzymały, Jana Poplatka, Władysława Smereki oraz Rajmunda Pietkiewicza ${ }^{20}$.

W niniejszym artykule próbuję ustalić, czy na podstawie porównania oryginalnych Wujkowych wydań Nowego Testamentu z lat 1593 i 1594 z poprawioną Biblią z roku 1599 oraz analizą odnotowanych różnic możliwe jest sformułowanie wniosków dotyczących cenzury przekładu w latach 1597-1598. Poszukiwałem odpowiedzi na pytania, czy na podstawie badań odtekstowych możliwe jest zrekonstruowanie podziału prac między jezuitami, tzn. wskazanie, które księgi poprawiane były przez tę samą osobę; czy można ustalić, ilu jezuitów weryfikowało przekład Wujka, a zatem zweryfikować informacje obecne w źródłach, i wreszcie - co można stwierdzić na temat przebiegu prac i przyjętej przez cenzorów strategii translatorskiej.

Wstępna częściowa rekonstrukcja podziału prac nad weryfikacją przekładu Nowego Testamentu Jakuba Wujka prowadzoną w latach 1597-1598 przez jezuicką komisję cenzorów opiera się na wynikach analizy porównawczej dotyczącej niekonsekwencji zmian ekwiwalentów wybranych łacińskich leksemów i fraz. Zgodnie z zastrzeżeniami i deklaracjami cenzorów, że podstawą tekstową katolickiego przekładu Biblii na język wernakularny może być wyłącznie tekst łaciński zaaprobowany przez Kościół, oraz rozpoznaniami badawczymi w zakresie pracy jezuitów nad cenzurą przekładu Wujka ${ }^{21}$ podstawowym punktem odniesienia w analizach była Wulgata. Niemniej jednak odwoływałem się również do greckiego Nowego Testamentu w celu uniknięcia możliwych zaburzeń wyników, gdyby któryś z cenzorów Wujka nie korzystał wyłącznie z tekstu łacińskiego ${ }^{22}$. Stosownie do postulatu sformułowanego

19 Por. R. Pietkiewicz, Problematyka żydowska w Biblii księdza Jakuba Wujka z 1599 roku. Studium źródet, dz. cyt., s. 282-283, przypisy 17-18; J. Poplatek, Obecny stan badań nad życiem Jakuba Wujka T.J. i program dalszej pracy, dz. cyt., s. 65.

20 Por. K. Drzymała, dz. cyt.; J. Poplatek, Obecny stan badań nad życiem Jakuba Wujka T.J. i program dalszej pracy, dz. cyt.; W. Smereka, Wstęp, dz. cyt.; R. Pietkiewicz, Biblia w tłumaczeniu ks. Jakuba Wujka (od 1593 r.), [w:] Biblia Polonorum..., dz. cyt., t. 1, s. 452-479.

21 Por. K. Drzymała, Wpływ księdza Stanisława Grodzickiego T.J. na tłumaczenie Biblii ks. Jakuba Wujka T.J., dz. cyt.; K. Gąsiorowski, Dwa psatterze ks. Wujka, dz. cyt.; J. Frankowski, Psatterz Dawidów z 1594 roku w przekładzie ks. Jakuba Wujka i jego znaczenie, [w:] Psałterz Dawidów w przekładzie ks. Jakuba Wujka z 1594 roku, oprac. J. Frankowski, Warszawa 1993, s. 16-17.

22 Ślady takiej praktyki widać w komentarzach dodanych przez cenzorów w Biblii z roku 1599, które odnoszą się do tekstu greckiego. Takie uwagi zamieszczono w Mt 3, 7; 18, 6; 19, 17; Łk 11, 53; 15, 16; 16, 1; J 6, 45; 14, 26; 16, 8; Hbr 7, 24; 1 J 5, 40. 
przez Rajmunda Pietkiewicza ${ }^{23}$ prace prowadziłem na łacińskich i greckich wydaniach Nowego Testamentu, z których korzystali Wujek i cenzorzy.

W cytatach z polskich starych druków zmodernizowano grafię i interpunkcję oraz rozwinięto wszystkie skróty i ligatury. W przytoczeniach tekstów greckich (za Biblia regia ${ }^{24}$ ) i łacińskich zachowano oryginalną grafię oraz interpunkcję, rozwinięto za to skróty i ligatury. Wszystkie cytaty z łacińskiego Nowego Testamentu pochodzą z Wulgaty syksto-klementyńskiej z roku $1593^{25}$, można traktować je jednak jako równobrzmiące (z wyjątkiem interpunkcji) z Wulgatą lowańską ${ }^{26}$ oraz Wulgatą syksto-klementyńską z roku $1592^{27}$ wszelkie różnice między tymi wydaniami odnotowano w przypisach bądź tekście głównym.

Punktem wyjścia jest hipoteza, że daną księgę w całości weryfikował jeden cenzor. Jest to założenie konieczne do podjęcia jakichkolwiek badań w tym obszarze, niemniej jednak wymaga weryfikacji w toku analiz. Szczegółowe wyniki obserwacji tekstualnych dowodzą jego słuszności - przynajmniej

23 Por. R. Pietkiewicz, Problematyka żydowska w Biblii księdza Jakuba Wujka z 1599 roku. Studium źródet, dz. cyt., s. 298.

24

Biblia Sacra Hebraice, Chaldaice, Graece, et Latine: Philippi II. Reg. Catho. Pietate, et studio ad sacrosanctae Ecclesiae usum [...], vol. 5: Novum Iesu Christi D. N. Testamentum [...], excudebat Christophorus Plantinus Regius Prototypographus, Antverpiae 1571. Wydanie, tzw. „poliglota antwerpska”, zawierało m.in. grecki tekst Nowego Testamentu traktowany przez Wujka jako podstawa przekładu przy pracach nad Nowym Testamentem wydanym w roku 1593, prawdopodobnie była również wykorzystywana przez cenzorów - por. R. Pietkiewicz, Biblia Polonorum..., s. 459. Na używanie przez cenzorów tej edycji wskazuje fragment komentarza do Dz 2, 42 dodany przez cenzora w Biblii z roku 1599: „w syriackim tekście jest słowo, które znaczy «Eucharystia»”. Na podstawie brzmienia tego fragmentu można przypuszczać, że cenzor nie znał języka syriackiego (brak transkrypcji na alfabet łaciński), ale informację tę zaczerpnął „z drugiej ręki”. W Biblia regia obok tekstu syriackiego znajduje się jego łacińska interpretacja (w tym wypadku: „Et perseuerabant in [...] fractione Eucharistiae), a kompletne wydanie w dwóch egzemplarzach przechowywała biblioteka kolegium poznańskiego, gdzie pracowali cenzorzy - por. Catalog librorum bibliothecae Colegii [!] Posnaniensis Societatis Iesu a patribus eiusdem Societatis editorum [...] 1610, Polska Akademia Nauk Biblioteka Kórnicka, sygn. BK 11249, s. 3.

Biblia Sacra Vulgatae eiditonis [...]. Ex typographia Apostolica Vaticana, Romae 1593. Na tej edycji Wulgaty pracowali cenzorzy poprawiający przekład Wujka w latach 1597-1598 - por. K. Drzymała, Wpływ księdza Stanisława Grodzickiego T.J. na tłumaczenie Biblii ks. Jakuba Wujka T.J., dz. cyt., s. 72 Biblia Sacra quid, in hac editione, a Theologis Lovaniensibus, preestitum sit, paulo post indicatur. Ex officina Christophori Plantini, Architypographi Regii, Antverpiae 1574. Ten druk stanowił łacińską podstawę tekstową wydania Nowego Testamentu w roku 1593, por. R. Pietkiewicz, Biblia Polonorum..., dz. cyt., t. 1, s. 459.

27 Biblia Sacra Vulgatae editionis [...]. Ex typographia Apostolica Vaticana, Romae 1592. To wydanie stanowiło podstawę zmian wprowadzonych przez Wujka w Nowym Testamencie z roku 1594 w stosunku do wydania z roku 1593, por. R. Pietkiewicz, Biblia Polonorum..., dz. cyt., t. 1, s. 457, 459. 
w wypadku części Nowego Testamentu (o czym dalej). Ze względu na tę hipotezę w badaniach nie uwzględniłem Listów Apostolskich. Poszczególne epistoły o różnym autorstwie mogły zostać podzielone między kilku jezuitów, a relatywnie niewielka objętość poszczególnych ksiąg nie pozwoliłaby na wyciąganie daleko idących wniosków.

Analizą zostały objęte ekwiwalenty większej grupy łacińskich leksemów: abire, accedere, admiror, adolescentus, adulterium, adulterus, agrum, ancilla, aroma, atrium, azyma, candelabrum, castellum, centurio, circumire, coinquinare, colaphis cadere, colaphizare, comminare, communicare, communicatio, comitor, congregari, contradicere, contristare, conparticeps, conservus, convenire, conversari, destruere, discumbere, eligere, exsurgere, filiolus, filius, fornicari, fornicatio, gloria, haeresis, increpare, infantus, ingredior, inquietari, inquinare, intelligere, iterum, liberare, litigare, littera, lugere, magnificare, maledicere, mandatum, mens, meretrix, miror, misereor, moechari, nequitia, pars, participatio, parvulus, pascha, passio, peccatum, perdere, pertransire, poenitere, poenitentia, pontifex, possesio, possidere, praedicare, praeire, praeses, prandere, primum, princeps, sacerdos, puer, purpura, ramus, redemptio, refectio, reprobatus, requies, sabbatum, societas, socius, solvere, sudarium, supervenire, spernare, timor, traditio, tribunus, tributum, triticum, unigenitus, vestis, vicus, villa, vuas oraz połączeń składniowych: a daemonio vexari, caput anguli, daemonium habere, dies festus. Jak ujawniło skolacjonowanie wydań, te właśnie leksemy i frazy były przez cenzorów modyfikowane niekonsekwentnie.

Różnice w zmianach wprowadzanych przez cenzorów w obrębie ekwiwalentów czternastu spośród analizowanych leksemów i fraz dostarczyły przesłanek do podziału prac między jezuitami. W niniejszym artykule omówiłem jedenaście z nich. Jako ilustrację metody badań przedstawiłem centurio oraz tribunus, a w dalszej części artykułu znajdują omówienie następujące wyrazy: pascha, daemonium habere, convenire, conservus, candelabrum, caput anguli, purpura, contradicere oraz litigare. Pominąłem coinquinare, destruo oraz exsurgo.

Uzyskane przesłanki - redukowalne do postaci twierdzenia, że danych dwóch ksiąg nie poprawiał ten sam cenzor - nie są jednak równoważne. Wiele z nich pochodzi z analizy wyrazów bądź fraz o niskiej frekwencji w Nowym Testamencie (candelabrum, caput anguli, purpura, circuire, litigare), część zmian w obrębie poszczególnych ksiąg jest niekonsekwentna (convenire) albo dotyczy wyłącznie szczególnego związku syntaktycznego danego leksemu (tribunus) i mogą być traktowane wyłącznie jako poszlaki. Niektóre z przesłanek można jednak zakwalifikować jako rozstrzygające. Dotyczy to wyrazów bądź 
fraz o wysokiej frekwencji i modyfikowanych bądź pozostawianych systematycznie w obrębie konkretnych ksiąg (centurio, pascha, daemonium habere) oraz przeciwstawnych zmian w obrębie danych ksiąg (conservus oraz contradicere). Należy przez to rozumieć sytuacje, gdy w dwóch księgach tłumaczenie danego leksemu z podstawy łacińskiej w edycji Biblii z roku 1599 ujednolicono do dwóch różnych z wariantywnych ekwiwalentów z Wujkowego przekładu Nowego Testamentu z lat 1593 i 1594. Tak stało się na przykład w wypadku conservus, który przez Wujka był tłumaczony jako „towarzysz” (Mt 18, 29. 31. 33; 24, 49; Ap 6,11) albo „spółsługa” (Ap 19, 10; 22, 9) oraz jednokrotnie przez parafrazę „ktoś, kto z kimś służy” (Mt 18, 28). Cenzor Mt zmienił Wujkową parafrazę o znaczeniu „spółsługa” na „towarzysz”, natomiast cenzor Ap zdecydował się na ujednolicenie ekwiwalentów conservus do postaci „spółsługa”.

\section{Centurio, tribunus}

Badania prowadziłem w czterech etapach, opisanych poniżej wraz z przykładowymi analizami wyrazu „rotmistrz” jako odpowiednika łacińskich leksemów centurio oraz tribunus:

1) Na podstawie skolacjonowania ksiąg Nowego Testamentu z wydań z lat 1593, 1594 i 1599 wytypowałem polskie wyrazy oraz połączenia składniowe, które podlegały niekonsekwentnym zmianom, a tym samym potencjalnie mogą świadczyć o podziale pracy między audytorami. Wszelkie zmiany wprowadzone przez Wujka w Nowym Testamencie z roku 1594, które w obrębie analizowanych miejsc dotyczyły badanych leksemów oraz fraz, wskazałem w przypisach lub omówiłem w toku wywodu.

Przykład: Używany przez Jakuba Wujka wyraz „rotmistrz” w przeważającej części wypadków został zachowany (Mk 15, 39. 44-45; Łk 7, 2. 6; 23, 47; J 18, 12; Dz 10, 1. 22; 21, 32; 22, 25; 23, 17; 24, 23; 27, 1. 6. 11. 31. 43) w innych był zmieniany na „setnik” (Mt 8, 5. 8. 13; 27, 54) albo na „tysiącznik” (Mk 6, 21; Ap $\left.6,14\langle 15\rangle^{28} ; 19,18\right)$.

2) Wstępnie wytypowane miejsca porównałem z wydaniami Wulgaty stanowiącymi podstawę przekładu w poszczególnych edycjach Nowego Testamentu.

28 Podział wersetów w wydaniach Wujka w niektórych wypadkach odbiega od współczesnego. W nawiasach ostrokątnych wskazałem numerację Wujka w wydaniach Nowego Testamentu z lat 1593, 1594 i Biblii z roku 1599. 
Miało to na celu, po pierwsze, określenie łacińskiego odpowiednika bądź odpowiedników danego polskiego leksemu oraz, po drugie, wykluczenie z analizy różnic między wydaniami Nowego Testamentu, które wynikałyby ze zmian w łacińskiej podstawie przekładu (w obrębie analizowanych leksemów i połączeń syntaktycznych nie stwierdziłem jednak takich różnic).

Przykład: Analiza miejsc, w których w przekładzie Wujka pojawia się słowo „rotmistrz”, wykazała, że odpowiadają mu dwa leksemy łacińskie: centurio (Mt 8, 5. 8. 13; 27, 54; Mk 15, 39. 44-45; Łk 7, 2. 6; 23, 47; Dz 10, 1. 22; 21, 32; 22, 25; 23, 17. 23; 24, 23; 27, 1. 6. 11. 31. 43) oraz tribunus (Mk 6, 21; J 18, 12; Dz 21, 31, Ap 6, 15; 9, 18). Wujkowy „rotmistrz” jako odpowiednik tribunus został zmieniony na „tysiącznika” (Mt 6, 21; Ap 6, $14\langle 15\rangle$; 19, 18) z wyjątkiem J 18, 12, gdzie pozostawiono „rotmistrza”. „Rotmistrz” jako odpowiednik centurio został albo zachowany (Mk 15, 39. 44-45; Łk 7, 2. 6; 23, 47; Dz 10, 1. 22; 21, 32; 22, 25; 23, 17. 23; 24, 23; 27, 1. 6. 11. 31. 43), albo zmieniony na „setnik” (Mt 8, 5. 8. 13; 27, 54). O podziale pracy między cenzorami mogą więc świadczyć niekonsekwencje w podejściu do słowa „rotmistrz” jako odpowiednika centurio, tzn. zmiana na „setnik” lub jej brak.

3) Ustaliłem pełną dystrybucję danych łacińskich leksemów i połączeń syntaktycznych na podstawie Analytical Lexicon of the Vulgate ${ }^{29}$. W każdym wypadku weryfikowałem poprawność danych w odniesieniu do wydań Wulgaty: lowańskiej z roku 1574 oraz syksto-klementyńskiej z lat 1592 i 1593 (w obrębie analizowanych fragmentów nie stwierdziłem jednak różnic między wydaniami, które dotyczyłyby omawianych leksemów i połączeń syntaktycznych). Celem tego etapu było uzyskanie pewności, że żadne miejsce, w którym pojawia się dany łaciński leksem, nie zostało pominięte.

Przykład: Weryfikacja dystrybucji leksemu centurio pozwoliła stwierdzić, że był przez Wujka bez wyjątków przekładany jako „rotmistrz” oraz że lista miejsc, w których się pojawił, była kompletna. Z kolei w wypadku wyrazu tribunus analiza ujawniła, że Wujek oddawał go w swoich przekładach dwojako: oprócz „rotmistrza” wprowadzał również rzeczownik „hetman”, który każdorazowo został przez cenzorów zmieniony na „tysiącznik” (Mk 6, 21; Dz 21, 31-33; 21, 37; 22, 24. 26-29; 23, 10. 15. 17-19. 22; 24, 7. 22; 25, 23).

4) $\mathrm{W}$ ostatnim etapie analizy sprawdzałem, czy w konkretnych księgach dana zmiana polskiego odpowiednika łacińskiego leksemu była wprowadzana

29 A. Curtis, I. Hoogendyk, Analytical Lexicon of the Vulgate, Faithlife 2017, https://www.logos.com/ product/148408/analytical-lexicon-of-the-vulgate. 
konsekwentnie lub niekonsekwentnie. Dzięki temu możliwe było uzyskanie przesłanek dotyczących podziału prac między cenzorami. Za tego rodzaju przesłanki uznawałem wyłącznie odmienność zmian wprowadzanych w poszczególnych księgach, nie zaś tożsamość tychże modyfikacji. Na tym etapie uwzględniałem również kontekst danego wystąpienia leksemu, który mógł zadecydować o wprowadzeniu bądź niewprowadzeniu przez cenzora zmiany w konkretnej sytuacji, co z kolei pozwoliło wyjaśnić część niekonsekwencji. Aby wykluczyć potencjalne modyfikacje wynikające z konferowania przekładu przez cenzorów z greckim Nowym Testamentem (tj. wbrew deklarowanej strategii translatorskiej), wziąłem pod uwagę grecki tekst Nowego Testamentu z Biblia regia. Jako pomoc do poprawnej interpretacji form greckich służyło interlinearne grecko-polskie wydanie Nowego Testamentu ${ }^{30}$.

Przykład: Zmiana odpowiednika centurio na „setnik” była wprowadzana konsekwentnie w Mt, natomiast w Mk, Łk, J i Dz bez wyjątku pozostawio-

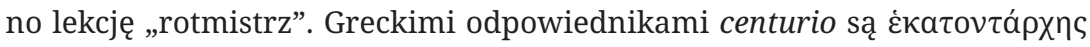
(Mt 8, 5. 13; 27, 54; Łk 7, 2. 6; 23, 47; Dz 10, 1. 22; 21, 32; 22, 25-26; 23, 17. 23;

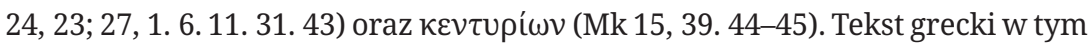
wypadku nie miał wpływu na przekład Wujka oraz zmiany wprowadzane przez cenzorów. Można wnioskować, że Mt poprawiał inny cenzor niż Mk, Łk, J i Dz. „Hetman” i „rotmistrz” jako odpowiedniki tribunus (w grece w każdym

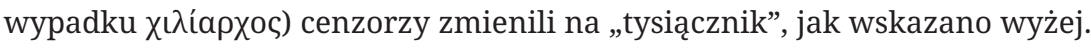
Wyjątek stanowi J 18, 12, gdzie zachowano „rotmistrza” jako odpowiednik tribunus. Pozwala to wnioskować, że J poprawiał inny cenzor niż Mk, Dz i Ap, w których wprowadzono zmiany, choć ze względu jednak na jednostkowy charakter omawianej różnicy trudno tu o jakąkolwiek pewność.

\section{Pascha}

Wyraz pascha w greckim Nowym Testamencie przyjmuje postać synkretyczną

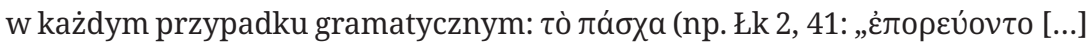

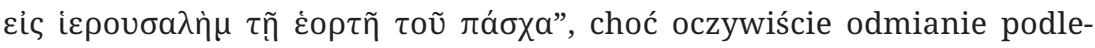
ga rodzajnik). W wydaniach Wulgaty, które stanowiły podstawę tekstową

30 Grecko-polski Nowy Testament. Wydanie interlinearne z kluczem gramatycznym, z kodami Stronga i Popowskiego oraz petna transliteracją greckiego tekstu, tłum. R. Popowski, M. Wojciechowski, Warszawa 2014. 
poszczególnych wydań samodzielnych tłumaczeń Wujka i ocenzurowanego, formy leksemu pascha są równobrzmiące z mianownikiem i wyizolowane z kontekstu, nie ujawniają przypadku (Mt 26, 2. 17-19; Mk 14, 1. 12.14.16; Łk 2, 41; 22, 1. 7-8. 11. 13. 15; J 2, 13. 23; 6, 4; 11, 55; 18, 28. 39; Dz 12, 4), np. „Quo vis eamus, et paremus tibi ut manduces Pascha?” (Mk 14, 12). Wyjątek stanowią trzy wystąpienia w J: „Iesus [...] ante sex dies Paschae venit Bethaniam” (12, 1), „Ante diem festum Paschae” $(13,1)$, „Erat autem parasceue Paschae" $(19,14)$.

W przekładzie Jakuba Wujka (Nowy Testament z lat 1593 i 1594) polska „pascha” podlega konsekwentnej odmianie (ściśle rzecz biorąc - występuje w formach charakterystycznych dla przypadków zależnych), np. Mk 14, 12: „Gdzie chcesz, abyśmyć szedłszy, nagotowali, żebyś jadł Paschę?” albo J 12, 1: „Jezus [...] sześć dni przed Paschą przyszedł do Betanijej”. Fleksja „paschy” została zachowana przez cenzorów w każdej księdze Biblii z roku 1599, w której pojawia się ten leksem: Mk, Łk, J, Dz. Wyjątek stanowi Mt, gdzie „pascha” przyjmuje postać synkretyczną w każdym przypadku gramatycznym: „po dwu dniu Pascha będzie” (mianownik - 26, 2), „Gdzie chcesz, abyśmyć zgotowali jeść Pascha?” (biernik - 26,17), „u ciebie czynię Pascha z uczniami mymi” (biernik - 26, 18), „zgotowali Pascha” (biernik - 26, 19). Można stąd wnioskować, że Mt poprawiał inny cenzor niż Mk, Łk, J i Dz. Przesłanka ta wydaje się rozstrzygająca - zmiany w stosunku do oryginalnej wersji Wujka wprowadzono tylko w jednej księdze i są całkowicie konsekwentne.

Warto jeszcze zwrócić uwagę na pojedynczy przykład z Mk 14, 1 w Biblii z roku 1599 - łączliwość syntaktyczna wyrazu pozwala stwierdzić, że ma on rodzaj nijaki: „było Pascha i przaśniki”, w Nowym Testamencie z lat 1593 i 1594 fraza brzmiała zaś: „była Pascha i święto przaśników”. Precyzyjne wskazanie rodzaju gramatycznego - w tym wypadku żeńskiego - możliwe jest jeszcze na podstawie trzech fraz „była pascha” w J 2, 13; 6, 4; 11, 55. Ponieważ jest to całkowicie odizolowana zmiana i może stanowić wynik omyłki zecera przy składzie tekstu, nie można jej traktować jako przesłanki rozstrzygającej o podziale prac między cenzorami.

\section{Daemonium habere}

W łacińskim Nowym Testamencie fraza daemonium habere pojawia się osiem-

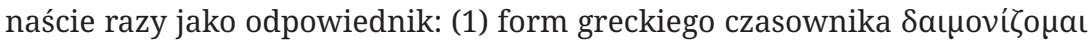




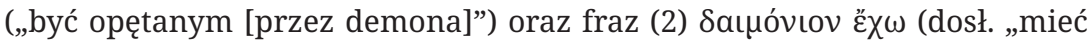

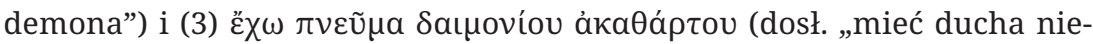
czystego demona", Wulgata: daemonium immundum habere). Jakub Wujek w Nowym Testamencie z lat 1593 i 1594 przekładał te frazy na dwa sposoby: „mieć czarta” oraz „być opętanym”, w części form imiesłowowych zaś, tj. $d a-$ emonium habens, w postaci dziś odbieranej jako zsubstantywizowana, czyli „opętany”, np. Mk 1, 32: „przynosili do niego [...] opętane”. Dystrybucję fraz i sposób ich oddawania przez Jakuba Wujka, a także zmiany wprowadzane przez cenzorów, przedstawia tabela 1.

Tabela 1. Daemonium habere. Dystrybucja frazy, greckie odpowiedniki, przekład Nowego Testamentu z roku 1593 i zmiana cenzorska w Biblii z roku 1599

\begin{tabular}{|c|c|c|c|c|c|}
\hline & Dystrybucja frazy & $\begin{array}{c}\text { Grecki odpowiednik } \\
\text { łac. frazy } \\
\text { daemonium habere }\end{array}$ & $\begin{array}{l}\text { Nowy Testament } \\
\text { z roku } 1593\end{array}$ & $\begin{array}{l}\text { Zmiana cenzorska } \\
\text { w Biblii z roku } 1599\end{array}$ & $\begin{array}{l}\text { Liczba poświad- } \\
\text { czeń w Nowym } \\
\text { Testamencie }\end{array}$ \\
\hline \multirow{2}{*}{ Mt } & 11,18 & 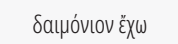 & mieć czarta & $-{ }^{31}$ & 1 \\
\hline & 4,$24 ; 8,16.28 .33 ; 9,32 ; 12,22$ & 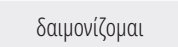 & być opętanym & mieć diabelstwo & 6 \\
\hline \multirow{2}{*}{ Mk } & 5,16 & \multirow{2}{*}{ 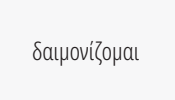 } & \multirow{2}{*}{ być opętanym } & mieć czarta & 1 \\
\hline & 1,32 & & & - & 1 \\
\hline \multirow[t]{2}{*}{ tk } & $4,33\langle 34\rangle$ & 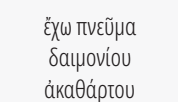 & $\begin{array}{l}\text { mieć czarta } \\
\text { nieczystego }\end{array}$ & \multirow[t]{2}{*}{ - } & 1 \\
\hline & 7,$33 ; 8,27$ & 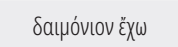 & mieć czarta & & 2 \\
\hline \multirow{3}{*}{ J } & 7,$20 ; 10,20$ & \multirow{2}{*}{ 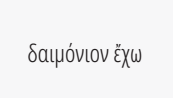 } & być opętanym ${ }^{32}$ & mieć diabelstwo & 2 \\
\hline & $8,48-49.52$ & & mieć czarta & - & 3 \\
\hline & 10,21 & 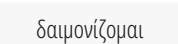 & być opętanym & mieć diabelstwo & 1 \\
\hline
\end{tabular}

Komentarza wymaga relacja przekładu Nowego Testamentu z roku 1593

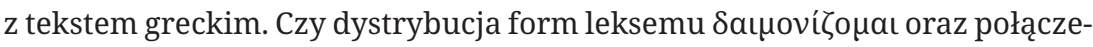

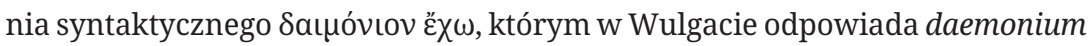

31 Tu i dalej „,-” oznacza brak modyfikacji przekładu przez cenzorów.

32 W Nowym Testamencie z 1594 roku Wujek wprowadził zmianę do J 10, 20-21 z „być opętanym” na „mieć czarta”. Cenzor, który w innych wypadkach pozostawiał frazę „mieć czarta”, w omawianych wersetach zmienił ją na „mieć diabelstwo”. Można stąd wnioskować, że podstawą jego pracy był Nowy Testament z roku 1593. 
habere, znajduje odzwierciedlenie w Wujkowym tłumaczeniu? Tak. Jak widać w tabeli 1, jedynym stosowanym przez Wujka w Nowym Testamencie z roku

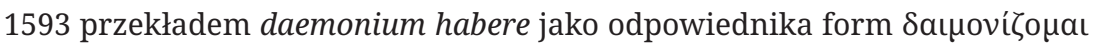
jest „być opętanym”, natomiast preferowany przez tłumacza ekwiwalent

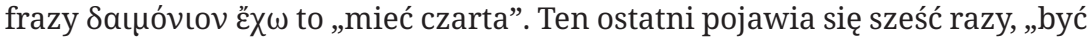
opętanym” zaś tylko dwukrotnie (ze względu na specyficzną kolokację pominąłem tutaj i dalej przypadek Łk 4, 33).

Należy w tym kontekście zwrócić uwagę na zmianę redakcyjną (bez związku z różnicami w kolejnych wydaniach Wulgaty) wprowadzoną przez Wujka w Nowym Testamencie z roku 1594: z „być opętanym” na „mieć

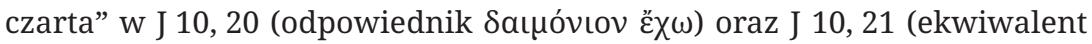

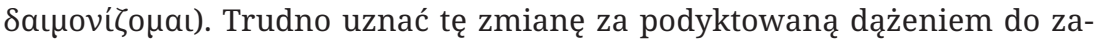
chowania spójności z tekstem greckim - choć w ten sposób Wujek uzyskał większą odpowiedniość między połączeniami syntaktycznymi „mieć czarta”

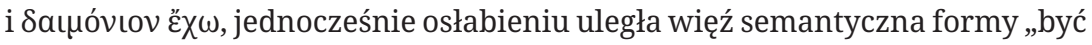

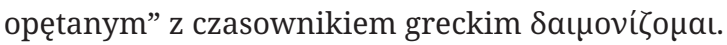

Formy $\delta a \iota \mu o v i ́ \zeta o \mu a \iota$ występują w Nowym Testamencie prawie wyłącz-

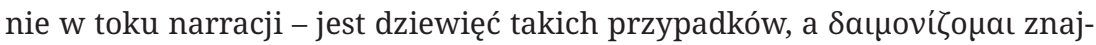
duje się w ośmiu z nich: Mt 4, 24; 8, 16. 28. 33; 9, 32; 12, 22; Mk 1, 32; 5, 16 ,

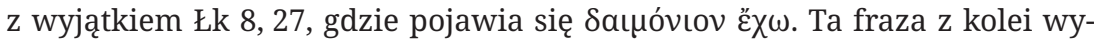
stępuje przeważnie w przytoczeniach wypowiedzi postaci o charakterze mowy zależnej bądź niezależnej w siedmiu z łącznie ośmiu miejsc tego typu: Mt 11, 18; Łk 7, 33; J 7, 20; 8, 48-49; 8, 52; 10, 20. W J 10, 21 pojawia się forma

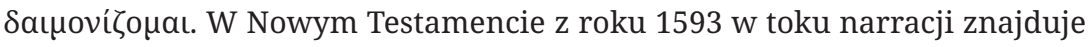
się „być opętanym” (oprócz Łk 8, 27: „mieć czarta”), w mowie zależnej lub niezależnej natomiast „mieć czarta” (poza J 7, 20 i 10, 20). Zmiana w Nowym Testamencie z roku 1594 usuwa jeden z wyjątków od tej hipotetycznej reguły w J 10, 20.

Reasumując, można przypuszczać, że Wujek rozpoznał konteksty, w jakich w greckim Nowym Testamencie pojawiają się omawiane formy, a zróżnicowanie wypowiedzi postaci, w których znajdują się konstrukcje charakterystyczne dla biblijnych sposobów wypowiedzi (w tym wypadku - greckiego Nowego Testamentu i Wulgaty) od narracji operującej formami właściwymi dla polszczyzny końca XVI wieku³3 (i zarazem odbiegającymi od Wulgaty,

33 Połączenie syntaktyczne „mieć czarta” występuje w XVI wieku wyłącznie w przekładach Biblii Jakuba Wujka iSzymona Budnego, por. A. Linda, Czart, [w:] Stownikpolszczyzny XVI wieku, t. 4, red. A. Cieńska, Wrocław 1969, s. 22-24. Formy wyrazów „opętać”, „opętanie”, „opętany” dominują w literaturze 
choć zgodnymi z greckim Nowym Testamentem) było w tym wypadku dla tłumacza istotniejsze od zachowania spójności odmiennych przekładów frazy daemonium habere $\mathrm{z}$ ich greckimi odpowiednikami.

Cenzorzy Biblii Jakuba Wujka w każdym wypadku zaakceptowali „mieć czarta” jako ekwiwalent frazy daemonium habere, modyfikowali także pod względem spójności z łaciną Wujkowe tłumaczenie „być opętanym” bez wzięcia pod uwagę niuansów przejętych z tekstu greckiego, uwzględnionych przez tłumacza, który w Nowym Testamencie z roku 1593 tworzył swego rodzaju warstwę zależności drugiego stopnia (obejmującą łacinę i grekę). W Mt oraz J w odpowiednio sześciu i trzech przypadkach, jak można wyczytać z tabeli 1, konsekwentnie wprowadzono zmianę na „mieć diabelstwo” (np. J 7, 20 według Nowego Testamentu z roku 1593: „Aboś opętany, któż cię szuka zabić?”, według Biblii z roku 1599: „Diabelstwo masz, kto cię szuka zabić?”). Cenzorzy tych ksiąg jednocześnie pozostawili odczytanie Wujka „mieć czarta” (np. J. 8, 48 według Nowego Testamentu z roku 1593: „Izali my niedobrze mówiemy, żeś ty jest Samarytan i czarta $w$ sobie $^{34}$ masz?”, według Biblii z roku 1599: „Izali my nie dobrze mówiemy, żeś ty jest Samarytan i czarta masz?”), co prowadzi do niekonsekwencji względem łacińskiej podstawy przekładu.

Tymczasem cenzor Mk, po pierwsze, w jednym wypadku zachował Wujkową lekcję „być opętanym” (1, 32 według Nowego Testamentu z roku 1593 i Biblii z roku 1599: „przynosili do niego wszystkie [...] opętane”), po drugie, w innym miejscu zastąpił ją frazą „mieć czarta” (5, 16 według Nowego Testamentu z roku 1593: „A ci, którzy to widzieli, opowiedzieli im, jako się przydało onemu opętanemu”, według Biblii z roku 1599: „I powiadali im, którzy widzieli, jako się przydało temu, który miał czarta”), a nie „diabelstwo” jak cenzorzy Mt i J. Dostarcza to przesłanki na rzecz twierdzenia, że Mk poprawiał inny jezuita niż Mt i J. Skonfrontowanie bezwyjątkowości stosunkowo licznych zmian w tych dwóch ewangeliach z niekonsekwencją w cenzurze Mk pozwala zakwalifikować tę przesłankę jako rozstrzygającą.

niebiblijnej, a także w samych przekładach Pisma Świętego, por. K. Klimkowa, Opętać, Opętanie, Opętany, [w:] Stownik polszczyzny XVI wieku, t. 21, Wrocław-Warszawa-Kraków 1992, s. 495-497.

34 Kursywa to zabieg typograficzny zastosowany w Nowym Testamencie z roku 1593 i oznacza wyrazy niemające bezpośredniej podstawy tekstowej w tekście greckim lub łacińskim, które zostały przez Jakuba Wujka dodane do przekładu w celu ułatwienia jego zrozumienia. 


\section{Convenire}

W Wulgacie formy wyrazu convenire pojawiają się wielokrotnie i odpowia-

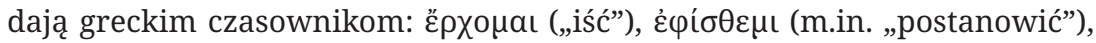

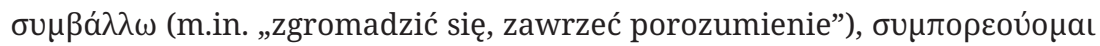

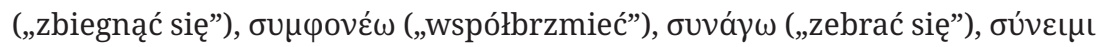

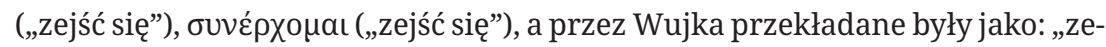
brać się”, ,zejść się”, „zmówić się”, ,zgromadzić się”, „zbiegnąć się”, ,przyjść”, „nie przystoi”, „umyślić”, „znaleźć (kogoś)”. Dystrybucję leksemu convenire i jego greckich odpowiedników, przekłady zaproponowane przez Wujka oraz zmiany wprowadzane przez cenzorów przedstawia tabela 2.

Tabela 2. Convenire. Dystrubucja leksemu, greckie odpowiedniki, przekład Nowego Testamentu z roku 1593 i zmiana cenzorska w Biblii z roku 1599

\begin{tabular}{|c|c|c|c|c|c|}
\hline & Dystrybucja frazy & $\begin{array}{c}\text { Grecki odpowiednik } \\
\text { łac. convenire }\end{array}$ & $\begin{array}{l}\text { Nowy Testament } \\
\text { z roku } 1593\end{array}$ & $\begin{array}{l}\text { Zmiana cenzorska } \\
\text { w Biblii z roku } 1599\end{array}$ & $\begin{array}{l}\text { Liczba poświad- } \\
\text { czeń w Nowym } \\
\text { Testamencie }\end{array}$ \\
\hline \multirow{4}{*}{$\mathrm{Mt}$} & 26,$57 ; 27,62$ & \multirow{2}{*}{ ouváyw } & zebraćsię & - & 2 \\
\hline & 22,34 & & \multirow{2}{*}{ zejść się } & - & 1 \\
\hline & 1,18 & 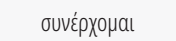 & & - & 1 \\
\hline & 20,13 & 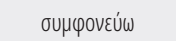 & zmówić się & - & 1 \\
\hline \multirow{8}{*}{ Mk } & 2,2 & \multirow{4}{*}{ ouváyw } & \multirow{2}{*}{ zebrać się } & - & 1 \\
\hline & 5,21 & & & \multirow{2}{*}{ zejść się } & 1 \\
\hline & 6,30 & & zgromadzić się & & 1 \\
\hline & 7,1 & & zejść się & - & 1 \\
\hline & 14,53 & \multirow{2}{*}{ 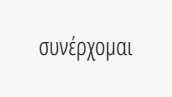 } & zejść się & - & 1 \\
\hline & 3,20 & & \multirow{2}{*}{ zbiegnąć się } & - & 1 \\
\hline & 10,1 & 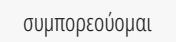 & & zejść się & 1 \\
\hline & 1,45 & 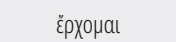 & przyjsiśc $^{35}$ & zejśśc się & 1 \\
\hline
\end{tabular}

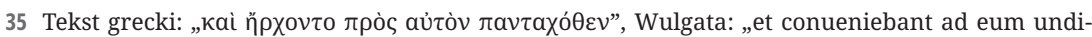
que”, Nowy Testament..., Kraków 1593: „zewsząd przychodzili do niego”, Biblia..., Kraków 1599: „zewsząd schodzili się do niego". 


\begin{tabular}{|c|c|c|c|c|c|}
\hline & Dystrybucja frazy & $\begin{array}{l}\text { Grecki odpowiednik } \\
\text { łac. convenire }\end{array}$ & $\begin{array}{l}\text { Nowy Testament } \\
\text { z roku } 1593\end{array}$ & $\begin{array}{l}\text { Zmiana cenzorska } \\
\text { w Biblii z roku } 1599\end{array}$ & $\begin{array}{l}\text { Liczba poświad- } \\
\text { czeń w Nowym } \\
\text { Testamencie }\end{array}$ \\
\hline \multirow{5}{*}{$Ł k$} & 22,66 & бuváyw & zejśćsię & - & 1 \\
\hline & 5,36 & 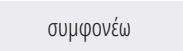 & nie przystoi ${ }^{36}$ & - & 1 \\
\hline & 5,15 & 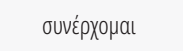 & zejśććsię & - & 1 \\
\hline & 8,4 & 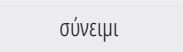 & zejść się & - & 1 \\
\hline & 20,1 & 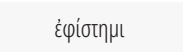 & zejśćcsię & - & 1 \\
\hline \multirow{2}{*}{ J } & 18,2 & бuváyw & zejśćć się & - & 1 \\
\hline & 18,20 & ouvépxoual & zejść się & - & 1 \\
\hline \multirow{9}{*}{$\mathrm{Dz}$} & 22,30 & \multirow{4}{*}{ ouváyw } & zejść się & - & 1 \\
\hline & 13,$44 ; 15,6$ & & zebraćsię & - & 2 \\
\hline & 4,27 & & \multirow{2}{*}{ zgromadzić się } & - & 1 \\
\hline & 4,26 & & & zejśśc się & 1 \\
\hline & $\begin{array}{c}1,6 ; 10,27 ; 16,13 ; 19,32 ; 20,7 ; \\
25,17 ; 28,17\end{array}$ & \multirow[t]{2}{*}{ бuvépXoual } & zejść się & - & 7 \\
\hline & 2,6 & & zbiegnąć się & - & 1 \\
\hline & 23,20 & 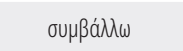 & umyślić & zmówić się & 1 \\
\hline & 20,14 & 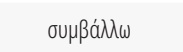 & znaleźć (kogoś) ${ }^{38}$ & przyjść (do kogoś) & 1 \\
\hline & 5,9 & 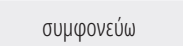 & zmówić się & - & 1 \\
\hline
\end{tabular}

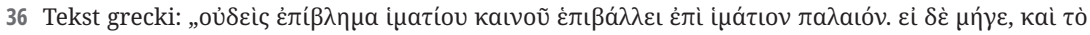

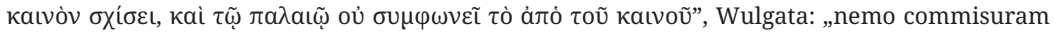
a nouo vestimento immittit in vestimentum vetus: alioquin et novum rumpit, et veteri non convenit commisura a novo”, Nowy Testament..., Kraków 1593: „żaden płata sukna nowego nie przyszywa do szaty starej, bo inaczej i nowe drze, i nie przystoi staremu płat od nowego”, Biblia..., Kraków 1599: „żaden płata od sukni nowej nie przyszywa do szaty starej, bo inaczej i nowe drze, i nie przystoi staremu płat od nowego".

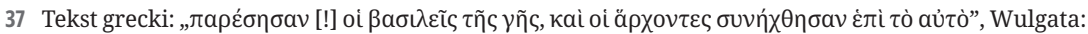
„Astiterunt reges terrae, et principes conuenerunt in unum”, Nowy Testament..., Kraków 1593: „Powstali królowie ziemie i książęta zgromadziły się wespółek”, Biblia..., Kraków 1599: „Stanęli królowie ziemscy i książęta zeszli się w gromadę".

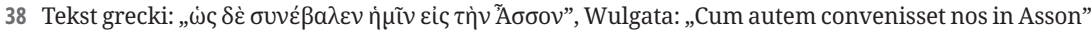
(w Wulgacie lowańskiej z roku 1574: „Cum autem invenisset nos in Asson”), Nowy Testament..., Kraków 1593: „A gdy nas znalazł [wyjaśnienie na marginesie: gdy się z nami zszedł] w Assonie”, Biblia..., Kraków 1599: „A gdy do nas przyszedł w Assonie”. 
I w tym wypadku na wybór konkretnego przekładu convenire przez Wujka miały wpływ odpowiedniki leksemu w greckim Nowym Testamencie. Jak widać w tabeli 2, preferowanym ekwiwalentem form czasownika ouvá $\gamma \omega$ było „zgromadzić się” oraz „zebrać się” (odpowiednio sześć i pięć razy), występuje także „zejść się” (trzykrotnie). Formy tego polskiego czasownika

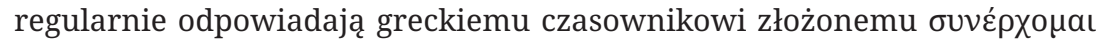
(jedenaście wystąpień) obok rzadszego tłumaczenia „zbiegnąć się” (dwa

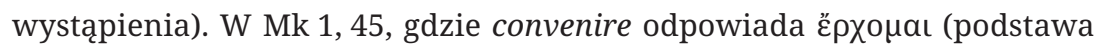

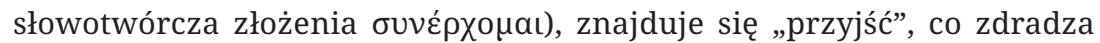
wpływ tekstu greckiego na przekład Nowego Testamentu z roku 1593, podobnie jak inne greckie czasowniki przełożone zgodnie z ich sensem ety-

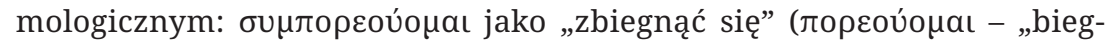

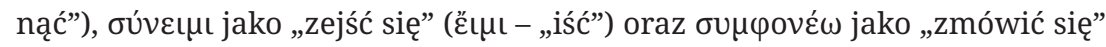

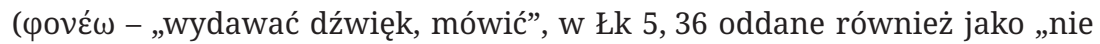
przystoi”). W Dz 20, 14 i 23, 20, gdzie convenire łączy się z $\sigma u \mu \beta a ́ \lambda \lambda \omega$, Wujek zaproponował odpowiednio „znaleźć kogoś” oraz „umyślić”, a w wypad-

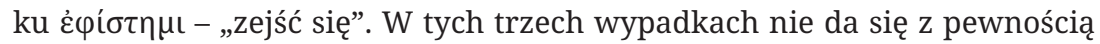
stwierdzić, czy tekst grecki został odzwierciedlony w Nowym Testamencie z roku 1593.

Wszystkie ekwiwalenty convenire w Nowym Testamencie z roku 1593 zostały zaakceptowane przez cenzorów Mt, J i Łk. W dwóch ostatnich wymienionych ewangeliach Wujek przekładał łaciński czasownik złożony polskimi formami „zejść się”39, tożsamymi pod względem etymologii, do których cenzorzy zgodnie ze stosowaną przez siebie strategią możliwie dosłownego oddawania Wulgaty nie powinni mieć żadnych zastrzeżeń. Zmiany wprowadzali wyłącznie cenzorzy Mk oraz Dz.

Pierwszy z nich (por. tabela 2) w czterech wypadkach wprowadził niezależną od tekstu greckiego zmianę na „zejść się”, nie akceptując form „zebrać się” (Mk 5, 21), „zgromadzić się” (6, 30), „Zbiegnąć się” (10,1) oraz „przyjść (1, 45). W ten sposób polskie odpowiedniki convenire zostały ujednolicone do postaci „zejść się”, jednakże z dwoma wyjątkami. W 2, 2 jezuita zachował Wujkową lekcję „zebrać się”, w 3, 20 zaś - „zbiegnąć się”. Konteksty, w których w tych dwóch wypadkach występują formy convenire, nie stanowiły przeszkody dla

39 Z wyjątkiem „nie przystoi” w specyficznej kolokacji w Łk 5, 36. 
wprowadzenia zmiany i są analogiczne do miejsc, które zmodyfikowano ${ }^{40}$. Prawdopodobnie więc te dwa miejsca uszły uwadze cenzora. Być może niekonsekwencja wprowadzania zmian stanowi cechę charakterystyczną jezuity, który pracował nad Mk (por. daemonium habere).

Cenzor Dz ingerował w przekład convenire trzykrotnie. Jego modyfikacje dotknęły 23, 20, gdzie „umyślić” zastąpił „zmówić się”, oraz 20,14 - w tym wersecie „znaleźć (kogoś)” zmodyfikował na „przyjść (do kogoś)”. W 4, 26 wprowadził jeszcze zmianę ze „zgromadzić się” na „zejść się”, ponieważ jednak w kolejnym wersecie zachował tożsamą lekcję, można przypuszczać że o modyfikacji w tym wypadku zadecydowały nie zastrzeżenia względem wyboru polskiego leksemu przez Wujka, a kontekst, w którym się pojawia. Można więc wnosić, że podobnie jak jezuita poprawiający Mt, a inaczej niż pracujący nad Mk, akceptował różnorodne rozwiązania Wujka: zachował zarówno formy „zbiegnąć się” (2, 6), „zebrać się” (13, 44; 15, 6), jak i „zgromadzić się” (4, 27).

Na podstawie omówionych w tym punkcie różnic w zmianach wprowadzanych przez cenzorów w poszczególnych księgach można wnosić, że cenzor Mk nie poprawiał ani Mt, ani Dz. Ze względu jednak na niekonsekwencję zmian w Mk oraz obecność pojedynczych zmian w Dz jest to słaba przesłanka, którą można traktować wyłącznie jako poszlakę.

\section{Conservus}

Jakub Wujek przekładał conservus ( $\sigma u ́ v \delta o u \lambda o \varsigma$ ) pojawiające się tylko w Mt i Ap jako „towarzysz” (Mt 18, 29. 31. 33; 24, 49; Ap 6, 11, np. Mt 18, 33: „Izali tedy i ty nie miałeś się zmiłować nad towarzyszem twoim”), jako „spółsługa” (Ap 19, 10; 22, 9, np. Ap 22, 9: „Patrz, nie czyń tego, bomci jest spółsługa twój”)

40 Mk 2, 2 według Nowy Testament..., Kraków 1593: „A wnet wiele się ich zebrało, tak iż się zmieścić nie mogli ani przede drzwiami”, Biblia..., Kraków 1599: „A wiele się ich zebrało, tak iż się zmieścić nie mogli ani u drzwi” („Et convenerunt multi, ita ut non caperet neque ad ianuam”); por. Mk 5, 21 według Nowy Testament..., Kraków 1593: „A gdy się zaś Jezus przeprawił w łodzi na drugą stronę, zebrała się do niego wielka rzesza”, Biblia..., Kraków 1599: „A gdy się zaś Jezus przeprawił w łodzi za morze, zeszła się do niego wielka rzesza” („Et cum transcendisset Iesus in naui rursum trans fretum, conuenit turba multa ad eum”); Mk 3, 20 według Nowy Testament..., Kraków 1593 i Biblia..., Kraków 1599: „I przyszli do domu, i zbiegła się zasię rzesza” („Et veniunt ad domum: et conuenit iterum turba”); por. Mk 10, 1 według Nowy Testament..., Kraków 1593: „przyszedł na granice judskie po onej stronie Jordanu i zbieżały się zaś do niego rzesze”, Biblia..., Kraków 1599: „przyszedł na granice żydowskiej ziemie za Jordanem i zeszły się zaś do niego rzesze” (,venit in fines Iudaeae ultra Iordanem: et conueniunt iterum turbae ad eum”). 
oraz jednokrotnie przez parafrazę o tymże znaczeniu: „ktoś, kto z kimś służy” (Mt 18, 28: „nalazł jednego z tych, co z nim służyli”). O ile cenzor Mt ujednolicił ekwiwalenty omawianego leksemu do „towarzysz” (w 18, 28), o tyle jezuita poprawiający Ap wyrównał je do postaci „spółsługa” (w 6, 11). Jako że są to przeciwstawne zmiany, można omówiony przykład uznać za rozstrzygający, że Mt i Ap nie poprawiała ta sama osoba.

\section{Candelabrum}

Leksem candelabrum ( $\lambda$ uxvíav) obecny w Mt 5, 15; Mk 4, 21; Łk 8, 16; 11, 33; Ap 1, 12-13. 20 (dwukrotnie); 2, 1. 5; 11, 4 Wujek oddawał jako „świecznik”. Jedynie cenzor Ap w każdym z siedmiu wypadków zmienił go na „lichtarz”. Ponieważ w ewangeliach leksem ten pojawia się tylko raz lub dwa, można wysnuć stąd słabą, poszlakową przesłankę, iż Mt, Mk i Łk poprawiał inny cenzor niż Ap.

\section{Caput anguli}

Połączenie syntaktyczne caput anguli pojawia się raz w każdej z ewangelii synoptycznych (Mt 21, 42; Mk 12, 10; Łk 20,17) w równobrzmiącej frazie (zarówno w Wulgacie, jak i greckim Nowym Testamencie; jest to cytat z Ps 117, 22): „Lapidem, quem reprobaverunt aedificantes, hic factus est in ca-

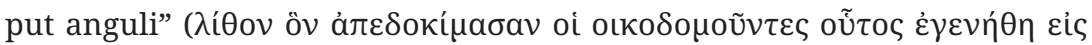

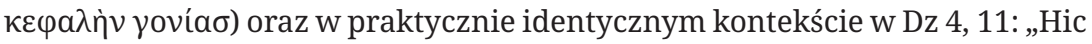
est lapis, qui reprobatus est a vobis aedificantibus, qui factus est in caput

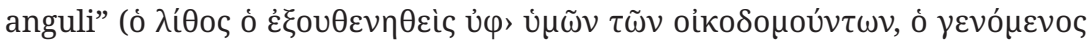

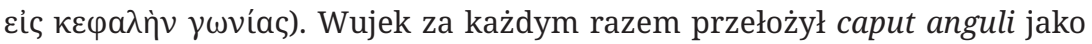
„głowa węgielna” (np. Mt 21, 42: „Kamień, który odrzucili budujący, ten się stał głową węgielną). Przydawka przymiotna została przez cenzorów zastąpiona zgodnie z tekstem łacińskim (oraz greckim) przydawką dopełniaczową: „głowa węgła” (w Mt 21, 42; Mk 12, 10; Dz 4, 11, np. Łk 20, 17: „Kamień, który odrzucili budownicy, ten się stał głową węgła”). Tylko cenzor Mk pozostawił oryginalną Wujkową lekcję (w 12, 10), co dostarcza słabej przesłanki (ze względu na jednostkowość przykładu) na rzecz twierdzenia, że nie pracował nad Mt, Łk i Dz. 


\section{Purpura}

Leksem purpura (лорфúpa) Wujek bez wyjątków przekładał jako „purpura”. Cenzorzy Mk (w 15, 17 i 15, 20) oraz Łk (w 16, 19) zachowali takie tłumaczenie, jedynie cenzor Ap zmienił je dwukrotnie na „szarłat” $(18,12$ i 18, 16). W innym wypadku $(17,4)$ pozostawił jednak odpowiednik proponowany przez Wujka. Jest to słaba przesłanka na rzecz twierdzenia, że Ap poprawiał inny cenzor niż Mk i Łk.

\section{Contradicere}

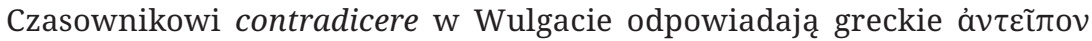

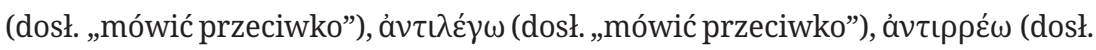

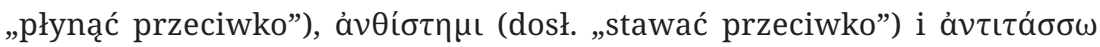
(dosł. ustawiać naprzeciw”). Wujek przekładał formy łacińskiego leksemu jako „być przeciw”, „mówić przeciw”, „sprzeciwiać się”, „zastawiać się”. Dystrybucję leksemu contradicere i jego greckich odpowiedników, przekłady zaproponowane przez Wujka oraz zmiany wprowadzane przez cenzorów przedstawia tabela 3.

Tabela 3. Contradicere. Dystrubucja leksemu, greckie odpowiedniki, przekład

Nowego Testamentu z roku 1593 i zmiana cenzorska w Biblii z roku 1599

\begin{tabular}{|c|c|c|c|c|c|}
\hline & Dystrybucja frazy & $\begin{array}{c}\text { Grecki odpowiednik } \\
\text { tac. contradicere }\end{array}$ & $\begin{array}{l}\text { Nowy Testament } \\
\text { z roku } 1593\end{array}$ & $\begin{array}{l}\text { Zmiana cenzorska } \\
\text { w Biblii z roku } 1599\end{array}$ & $\begin{array}{l}\text { Liczba poświadczeń } \\
\text { w Nowym Testamencie }\end{array}$ \\
\hline \multirow{2}{*}{ Łk } & 21,15 & 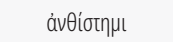 & sprzeciwiać się & - & 1 \\
\hline & 2,34 & \multirow{4}{*}{ 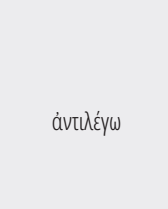 } & mówić przeciw & sprzeciwiać się & 1 \\
\hline J & 19,12 & & sprzeciwiać się & - & 1 \\
\hline \multirow{5}{*}{$\mathrm{Dz}$} & 13,$45 ; 28,22$ & & sprzeciwiać się & - & 2 \\
\hline & 28,19 & & być przeciw & sprzeciwiać się & 1 \\
\hline & 4,14 & ávtẽ̃̃ov & mówić przeciw & mówić przeciwko & 1 \\
\hline & 19,36 & 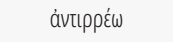 & sprzeciwiać się & mówić przeciw & 1 \\
\hline & 18,16 & 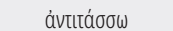 & zastawiać się & - & 1 \\
\hline
\end{tabular}


Jak widać w tabeli 3, w wypadku omawianego leksemu tekst grecki miał wpływ na przekład Nowego Testamenctu z roku 1593. Oprócz przekładu „sprzeciwiać się”, który można określić jako semantyczny ekwiwalent zarówno contradicere, jak i poszczególnych czasowników greckich, pojawiają się bowiem także przekłady oddające w polszczyźnie greckie struktury etymo-

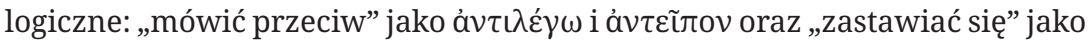

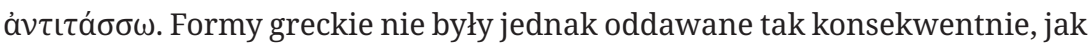
miało to miejsce w wypadku wyrazów omówionych w punktach daemonium habere i convenire.

Jedyne zmiany w obrębie przekładu contradicere wprowadzili cenzorzy Łk i Dz. Jak można wyczytać z tabeli 3, nie mieli na względzie tekstu greckiego. Jezuita poprawiający Łk wprowadził zmianę w 2, 34 przekładu Nowego Testamentu z roku 1593: „położon jest na upad i na powstanie wielu ich w Izraelu i na znak, przeciw któremu mówić będą” na „położon jest na upadek i na powstanie wielu w Izraelu i na znak, któremu sprzeciwiać się będą”. Osoba weryfikująca Dz zmodyfikowała w 28, 19 „być przeciw” na „sprzeciwiać się” oraz w 19, 36 według przekładu Nowego Testamentu z roku 1593: „Gdyż się tedy żaden temu sprzeciwić nie może” na „Gdyż się tedy przeciw temu mówić nie może” w Biblii z roku 1599. Ponadto w Biblii z roku 1599 w 4, 14 zamiast „mówić przeciw”, jak w przekładzie Nowego Testamentu z roku 1593, znajduje się „mówić przeciwko”, ale ta różnica wydaje się nieistotna.

Z omówionych przykładów można wysnuć rozstrzygającą przesłankę (ze względu na przeciwstawny charakter zmian), że Łk i Dz poprawiało dwóch różnych jezuitów,

\section{Litigare}

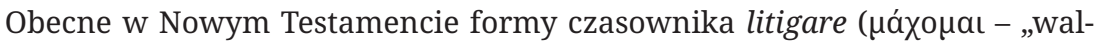
czyć”) Wujek przełożył jako „wadzić się” (J 6, 52; Dz 7, 26). Cenzor Dz zaakceptował przekład Wujka (7, 26: „A nazajutrz ukazał się im, gdy się wadzili”), z kolei cenzor J wprowadził zmianę na „swarzyć się”, modyfikując rozwiązanie Wujka w przekładzie Nowego Testamentu z roku 1593: „Wadzili się tedy Żydowie między sobą” na: „Swarzyli się tedy Żydowie między sobą” w przekładzie Biblii z roku 1599. Ten pojedynczy przypadek dostarcza poszlaki, że tych dwóch ksiąg nie poprawiał ten sam cenzor. 


\section{Podsumowanie}

Omówiony materiał potwierdza słuszność poczynionego na potrzeby analizy założenia, że daną księgę poprawiał w całości jeden jezuita. Oczywiście z pewnością można stwierdzić to w wypadku ksiąg, w których pojawiały się leksemy o stosunkowo dużej frekwencji, systematycznie modyfikowane bądź zachowywane w opozycji do innych ksiąg. Są to odosobnione w kontekście reszty Nowego Testamentu zmiany „rotmistrz” na „setnik” w Mt (centurio), brak fleksji słowa „pascha” w tejże ewangelii (pascha), bezwyjątkowa zmiana fraz „być opętanym” na „mieć diabelstwo” w Mt i J w opozycji do niesystematycznej modyfikacji na „mieć czarta” w Mk (daemonium habere), zachowanie różnorodności Wujkowych odpowiedników convenire w Mt i Dz w odróżnieniu od zmian na „zejść się” w Mk, a także konsekwentne zastępowanie „świecznika” „lichtarzem” występujące wyłącznie w Ap (candelabrum).

Uzyskane w wyniku przedstawionych analiz przesłanki o postaci twierdzeń, iż danych dwóch ksiąg nie poprawiał ten sam cenzor, zestawiłem w tabeli 4. Numery w rubrykach wskazują świadczące o tym zmiany w obrębie przekładu poszczególnych leksemów i fraz (1: centurio, 2: tribunus, 3: pascha, 4: daemonium habere, 5: convenire, 6: conservus, 7: candelabrum, 8: caput anguli, 9: purpura, 10: contradicere, 11: litigare). Pogrubieniem oznaczyłem przypadki zakwalifikowane jako rozstrzygające.

Tabela 4. Zestawienie przesłanek świadczących o przekładzie danych ksiąg przez różnych cenzorów

\begin{tabular}{|c|c|c|c|c|}
\hline & Mt & Mk & tk & J \\
\hline Mk & $\mathbf{1 , 3 , 4 , 5}$ & & & \\
\hline$k k$ & $\mathbf{1 , 3}, 8$ & 8 & & \\
\hline$J$ & $\mathbf{1 , 3}$ & 2,4 & & \\
\hline Dz & $\mathbf{1 , 3}$ & 5,8 & $\mathbf{1 0}$ & 2,11 \\
\hline Ap & $\mathbf{6 , 7}$ & 7,9 & 7,9 & 2 \\
\hline
\end{tabular}

$\mathrm{Z}$ danych zebranych w tabeli 4 na podstawie tylko rozstrzygających przypadków można wyciągnąć trzy wnioski: 
1) cenzor Mt nie weryfikował żadnych innych ksiąg Nowego Testamentu ${ }^{41}$ (poza, ewentualnie, Listami Apostolskimi lub ich częścią),

2) różni cenzorzy poprawiali J i Mk,

3) Łk i Dz nie poprawiali ci sami korektorzy.

Oznacza to, że w cenzurę przekładu Biblii Jakuba Wujka w latach 1597-1598 było zaangażowanych co najmniej trzech jezuitów.

Jeśli uwzględni się również przesłanki o poszlakowym charakterze, można pokusić się o hipotetyczny podział prac między jezuitami:

- cenzor I poprawiał tylko Mt;

- cenzor II - wyłącznie Mk;

- cenzor III - Łk,

- cenzor IV - Dz.

Ap mógł modyfikować albo cenzor IV, albo piąty jezuita - V, J zaś - cenzor III lub V (jeśli nie poprawiał Ap). W takim wypadku cenzorów musiałoby być co najmniej pięciu. Należy raz jeszcze podkreślić, że to czysto spekulatywna propozycja, oparta na nierozstrzygającym materiale.

Z omówionego materiału można wyciągnąć jednak jeszcze jeden istotny wniosek. Wytyczne, którymi cenzorzy kierowali się przy pracy, miały charakter ogólny i pozostawiały pewien margines swobody w podejmowaniu decyzji natury translatorsko-korektorskiej. Te z kolei nie były - przynajmniej w części przypadków - na bieżąco konsultowane i uzgadniane przez jezuitów pracujących przecież w tym samym miejscu i mogą świadczyć o ich indywidualnych preferencjach stylistycznych i leksykalnych, być może również o odmiennym rozumieniu podobnych fragmentów Pisma Świętego. Pozwala to żywić nadzieję, że planowana kontynuacja badań umożliwi dokładniejszą rekonstrukcję podziału pracy między cenzorami Biblii Jakuba Wujka. Nie można również wykluczyć, że po zebraniu większej ilości materiału oraz analizie zmian dotyczących również składni (rekcji czasowników, łączliwości składniowej, szyku wyrazów) możliwa będzie częściowa ekstrapolacja wniosków na Stary Testament.

41 Różnice w zmianach wprowadzanych w obrębie przekładu jeszcze trzech leksemów: coinquinare, destruo, exsurgo odróżniają Mt od Mk oraz, w wypadku destruo, od Łk. Ze względu jednak na rozstrzygający charakter przypadków 1, 3, 4, 6 nie omówiono ich w artykule. 


\section{Abstrakt}

\section{Cenzura przekładu Nowego Testamentu autorstwa Jakuba Wujka. Próba rekonstrukcji podziału prac między cenzorami}

Zgodnie z warunkiem postawionym przez generała Towarzystwa Jezusowego i papieża Grzegorza XIII przy udzielaniu zgody na polski przekład Biblii tłumaczenie Jakuba Wujka (zm. 1597) było weryfikowane przez komisję cenzorów zarówno podczas prac translatorskich, jak i po śmierci tłumacza. W niniejszym artykule na podstawie badań tekstowych nad niekonsekwencją zmian w poszczególnych księgach Nowego Testamentu autor przedstawia odpowiedzi na pytania badawcze: czy możliwe jest wskazanie, które księgi poprawiane były przez jedną osobę, czy można ustalić, ilu jezuitów weryfikowało przekład Wujka, i co można stwierdzić na temat przebiegu prac i przyjętej przez cenzorów strategii translatorskiej. Słowa kluczowe: Biblia, Nowy Testament, przekład, cenzura, Jakub Wujek, Stanisław Grodzicki, jezuici

\section{Abstract}

\section{Censorship of Jakub Wujek's Translation of the New Testament: An Attempt at a Reconstruction of the Division of Labor Between Censors}

Pursuant to the conditions set forth by the general of the Society of Jesus and Pope Gregory XIII regarding permission for the Polish translation of the Bible, Jakub Wujek's (d. 1597) rendering was verified by a commission of censors both while the translation was in progress and after the translator's death. In this article, the author responds to the research questions of if it is possible to indicate which books were edited by one person, if it can be established how many Jesuits verified Wujek's translation, and what we can say about the course of work and the translation strategy adopted by the censors on the basis of textual research on the inconsistency in the changes in individual books of the New Testament.

Keywords: Bible, New Testament, translation, censorship, Jakub Wujek, Stanisław Grodzicki, Jesuits

\section{References}

Arias Montanus, B., Plantin, C., Pagnino, S., Raphelengius, F., Le Fèvre, N., \& Le Fèvre de La Boderie, G. (Eds.). (25). Hebraicorvm Bibliorvm Veteris Testamenti Latina interpretatio. Christophorus Plantinus Regius Prototypographus [...] excudebat.

Baron, A., \& Pietras, H. (Eds.). (2007). Dokumenty Soborów Powszechnych. Tekst łaciński i polski: Vol. 4.1. Wydawnictwo WAM.

Biblia Sacra Hebraice, Chaldaice, Graece, et Latine: Philippi II. Reg. Catho. Pietate, et studio ad sacrosanctae Ecclesiae usum [...]: Vol. 5: Novum Iesu Christi D. N. Testamentum. (1571). Christophorus Plantinus.

Biblia Sacra quid, in hac editione, a Theologis Lovaniensibus, preestitum sit, paulo post indicatur. (1574). Officina Christophori Plantini.

Biblia Sacra Vulgatae editionis [...]. (1592). Typographia Apostolica Vaticana.

Biblia Sacra Vulgatae eiditonis [...]. (1593). Typographia Apostolica Vaticana.

Biblia to jest ksieggi Starego i Nowego Testamentu według łacińskiego przekładu starego, w kościele powszechnym przyjętego, na polski język znowu z pilnością przełożone [...] (J. Wujek, Trans.). (1599). Drukarnia Łazarzowa. 
Borysławska, G. (1981). Różnice między kolejnymi wydaniami Nowego Testamentu w przekładzie Jakuba Wujka. $1,3-18$.

Catalog librorum bibliothecae Colegii Posnaniensis Societatis Iesu a patribus eiusdem Societatis editorum [...] 1610 (BK 11249). (1938). Polska Akademia Nauk Biblioteka Kórnicka.

Czechowic, M. (1594). Plastr na wydanie Nowego Testamentu przez x. Jakuba Wujka. Aleksy Rodecki.

Frankowski, J. (Ed.). (1993). Psałterz Dawidów (J. Wujek, Trans.). Instytut Wydawniczy Pax.

Frick, D. A. (2018). Polska philologia sacra w czasach reformacji i kontrreformacji. Kilka kart z historii sporów wyznaniowych (1551-1632) (K. Szymańska, Trans.). wydano nakładem Wydziału Polonistyki Uniwersytetu Warszawskiego.

Gąsiorowski, K. (1959). Dwa psałterze ks. Wujka. Ruch Biblijny i Liturgiczny, 12(3), 246-259. https://doi.org/10.21906/ rbl.2719

Grecko-polski Nowy Testament. Wydanie interlinearne z kluczem gramatycznym, z kodami Stronga i Popowskiego oraz pelna transliteracja greckiego tekstu (R. Popowski \& M. Wojciechowski, Trans.; 9th ed.). (2014). Vocatio.

Hoogendyk, I., \& Curtis, A. (2017). Analytical Lexicon of the Vulgate. Faithlife. https://www.logos.com/product/148408/ analytical-lexicon-of-the-vulgate

Klimkowa, K. (1992a). Opętać. In Słownik polszczyzny XVI wieku (Vol. 21, pp. 495-496). Zakład Narodowy imienia Ossolińskich, Wydawnictwo Polskiej Akademii Nauk.

Klimkowa, K. (1992b). Opętanie. In Stownik polszczyzny XVI wieku (Vol. 21, p. 496). Zakład Narodowy imienia Ossolińskich, Wydawnictwo Polskiej Akademii Nauk.

Klimkowa, K. (1992c). Opętany. In Stownik polszczyzny XVI wieku (Vol. 21, pp. 496-497). Zakład Narodowy imienia Ossolińskich, Wydawnictwo Polskiej Akademii Nauk.

Kochanowicz, J. (2012). Początki piśmiennictwa jezuickiego w Polsce: Studium z historii kultury. Wydawnictwo Naukowe Dolnośląskiej Szkoły Wyższej.

Łaszcz, M. (1597). Recepta na plastr Czechowica ministra nowokrzczeńskiego [...]. Drukarnia Łazarzowa.

Linda, A. (1969). Opętany. In Stownik polszczyzny XVI wieku (Vol. 4, pp. 22-24). Zakład Narodowy imienia Ossolińskich, Wydawnictwo Polskiej Akademii Nauk.

Nowy Testament Pana naszego Jezusa Chrystusa, znowu z łacińskiego i greckiego na polskie wiernie a szczyrze przełożony (J. Wujek, Trans.). (1594). Drukarnia Andrzeja Piotrkowczyka.

Nowy Testament Pana naszego Jezusa Chrystusa, znowu z łacińskiego i z greckiego na polski wiernie a szczyrze przełożony i argumentami abo summariuszami każdych ksiag i rozdziałów, i annotacyjami po brzegach objaśniony [...] (J. Wujek, Trans.). (1593). Drukarnia Andrzeja Piotrkowczyka.

Pietkiewicz, R. (1951). Wpływ księdza Stanisława Grodzickiego T.J. na tłumaczenie Biblii ks. Jakuba Wujka T.J. Polonia Sacra, 4(1), 71-80.

Pietkiewicz, R. (2016). Biblia Polonorum. Historia Biblii w języku polskim: Vol. 1: Od początku do 1638 r. Wydawnictwo Pallottinum.

Pietkiewicz, R. (2020). Problematyka żydowska w Biblii księdza Jakuba Wujka z 1599 roku. The Biblical Annals, 10(2), 279-302. https://doi.org/10.31743/biban.4691

Poplatek, J. (1950). Obecny stan badań nad życiem Jakuba Wujka T.J. i program dalszej pracy. Polonia Sacra, 3(1-2), 20-91.

Psałterz Dawidów. Teraz znowu z łacińskiego, z greckiego i z żydowskiego na polski język z pilnościa przełożony [...] (J. Wujek, Trans.). (1594). Drukarnia Andrzeja Piotrkowczyka.

Smereka, W. (Ed.). (1966). Nowy Testament (J. Wujek, Trans.). Polskie Towarzystwo Teologiczne. 